\title{
The Organisation of Formal Education of Fencing Coaches in Hungary, Great Britain and the Czech Republic
}

\author{
Michal Roček, Vladimír Jůva, Kateřina Jakubcová
}

Faculty of Sports Studies, Masaryk University

\begin{abstract}
The paper deals with formal educational programmes for fencing coaches in Hungary, Great Britain and the Czech Republic. Based on a content analysis of mainly curricular documents, we were able to identify and describe similarities and differences in approaches to coach education. They were apparent primarily on the legislative, organisational and content levels. The research shows that the road to coaching excellence takes a different length of time in different countries. It is even in sharp contrast to formal licence education of some fencing federations when it comes to a bachelor study programme. Differences were also found in the approach towards the organisation of practical training. The more traditionally designed education of coaches in Hungary and the Czech Republic differed from the education in Great Britain from a philosophical and content point of view, specifically in topics such as the application of soft skills and setting, planning and assessment of goals in coaches' practice.
\end{abstract}

Keywords: coach education, fencing, fencing coach, coaching school, coaching projects

\section{INTRODUCTION}

Coach education is a term currently relevant to many sports, including fencing. Individual fencing federations develop and implement educational programmes for their coaches, often in collaboration with universities. They are aware of the fact that the main prerequisite of professional development is systematic and continuing education realised on formal, non-formal and informal levels (Dieffenbach \& Thompson, 2020; Trudel \& Gilbert, 2006; Marinková \& Stretti, 2009). It remains unclear what the ideal ratio between the individual forms is and which of them has the greatest effect on the increasing level of coach's skills (Reade, 2009; Mallett, Trudel, Lyle, \& Rynne, 2009). Some authors (e.g. Lyle, 2016) perceive the process as an intertwined system of formal and non-formal education. The road to becoming a coach, especially on the elite level, is a complex process that does not follow a stable and precise pattern (Janíková, Jůva, \& Cacek, 2019). For this reason, there are many ways of describing and clarifying the phenomenon.

Many authors decided to focus on research of coaching elites in which they give examples of best practices based on results. These empirical studies reflect the trends to conduct research on examples of successful coaches or athletes (how they train or trained in the past) and coaching education programmes they completed (Avard, 1995). Other authors decided to focus on the evaluation of specialised knowledge of coaches which they used to design educational models (Côté, Salmela, Trudel, Baria, \& Russel, 1995). There is a growing criticism of classical approaches based on levels of education in the model novice - expert where coaches can not focus on a specific part central to their research interest (Trudel \& Gilbert, 2006). The effort to theoretically define and describe the process that would be approved by experts when designing formal coach education was greatly assisted by a non-profit organisation International Council for Coaching Excellence - ICCE $E^{1}$ currently considered to be the leader in this research field. It is, in particular,

ICCE - https://www.icce.ws/ 
the documents The International Sport Coaching Bachelor Degree Standards of the International Council for Coaching Excellence (Lara-Bercial et al., 2016) and The International Sport Coaching Framework, Version 1.2. (ICCE, ASOIF, \& LBU, 2013) that substantially contribute to the design of new functional systems of education. In the USA, the system QCF - Quality Coaching Framework (United States Olympic Committee, 2017) was developed. These documents provide valuable information on the principles of the development of systems of coach education. Specific information on what, how and when to teach is stated in a study by Hedlund, Fletcher, Pack and Dahlin (2018).

Another problem transcending the boundaries of specialisation faced by universities, sports federations and organisers of formal coach education is the national legislative and accreditation conditions that define, to a great extent, the content, form, and length of formal educational programmes. The particular issue of coach education in fencing is dealt by, e.g. Kirby (2014), Kundera (2019a, 2019b) and Roček (2020a). In the wider practical and theoretical context as well as in the approach to education in individual sports disciplines, there is a growing interest in this topic in the Czech Republic (Gállová \& Jůva, 2019; Taušová, 2012; Tomešová, 2020; Janíková, Jůva \& Cacek, 2019; Kovár. 2011).

The aim of the present paper is to describe and compare formal educational programmes for fencing coaches in Great Britain, the Czech Republic and Hungary mainly with respect to the aspects of legislation, content, time allocation and organisation. In addition, attention will be paid to the conception of practical training and support in terms of study and teaching materials.

\section{RESEARCH METHODOLOGY}

The countries whose formal systems of coach education were compared were not chosen at random. Historically, Hungary belongs to the three most successful countries in the sport. Great Britain went through several functional changes of its educational system between 2007 and 2017 and recorded a general increase in the performance of its fencers (Randall, 2009; Jones, 2017). The main aim of the study was to compare the selected systems of formal education, identify and describe the similarities and differences in the approaches to coach education by means of content analysis (Hendl, 2005; Gavora 2010). After completing the heuristic stage of the research (Bartoš, 1992; Hroch, 1985), we designed a system of categories focusing on specific partial goals related to the description of:

1 - the legislation associated with the process of formal education of fencing coaches in the selected countries;

2- organisations providing fencing coach education;

3- organisational and content matter of courses and study programmes;

4- time allocation for individual levels of education;

5-practical training;

6- study materials provided for course attendees.

We used both quantitative and qualitative approach in content analysis (Macnamara, 2018; Berelson, 1952) of official documents of the studied institutions, educational programmes and their respective curricular documents and literature. This method was also used because it allows the application of descriptive functions (Švec, 2009). The information sources were mainly electronic and were consulted by correspondence and verified by experts on the studied area.

To compare the studied systems, we used a model based on description $\rightarrow$ interpretation $\rightarrow$ juxtaposition $\rightarrow$ and the actual comparison according to Bereday's model (Bereday, 1964). The model is typically used in curricular analyses, mainly in the area of educational science (Maňák 
\& Švec, 2005). Based on the information gained in the heuristic stage of the preparation, we were able to create a system of categories that were subsequently compared.

\section{RESULTS}

\section{The system of fencing coach education in the Czech Republic}

The education of fencing coaches in the Czech Republic is based on a 4-tier educational system described in a document Regulations and Criteria of Coaching Licences (https://www.czechfencing. cz/uploads/documents/119.pdf). It is a model of gradually increasing levels: fencing practitioner, $\mathrm{C}$ licence coach, B licence coach, A licence coach. A specific feature of the system is a degree for coaches with meritorious service, which is independent of the formal education of fencing coaches and is awarded for successful long-term work, especially on the occasion of the awarded coaches' anniversaries.

In the past, the education of fencing coaches was provided by the central organs of the Czech Union of Sport and after its disintegration in 1990, the individual unions (federations) were given freedom to design the system of education for their coaches. Over time, Czech fencing achieved a number of international successes. However, it became obvious that the conservative system of education could no longer reflect the current trends in the training of coaches and subsequently athletes, especially when it came to practical training (Kundera, 2019a). In 2020 the Educational and Methodological Committee (EMC) was established, aiming to innovate the system of education of fencing coaches. One of the first policies introduced by the committee was conducting of a survey $(\mathrm{n}=101)$ whose aim was to help instructors modify the current education of fencing coaches in the Czech Republic (for more, see Roček, 2020b).

Table 1. Overview of Czech fencing coach education provided by the Czech Fencing Federation and the Coaching School of the Faculty of Physical Education and Sport (FPES) Charles University

\begin{tabular}{|c|c|c|c|c|}
\hline & Practitioner & C licence coach & B licence coach & A licence coach \\
\hline Time allocation & 12 hours & 30 hours & 150 hours & 500 hours \\
\hline Age limit & $\begin{array}{l}>16 \text { years } \\
\text { of age }\end{array}$ & $>17$ years of age & $>18$ years of age & $>18$ years of age \\
\hline $\begin{array}{l}\text { Qualification pre- } \\
\text { requisites / fencing } \\
\text { experience }\end{array}$ & & $\begin{array}{l}\text { Practitioner, coaching } \\
\text { practice of min. } 1 \text { year } \\
\text { or } 4 \text { years of competi- } \\
\text { tion activity }\end{array}$ & $\begin{array}{l}\text { C licence coach, } \\
\text { coaching practice of } \\
\text { min. } 2 \text { years or min. } \\
6 \text { years of competi- } \\
\text { tion activity, min. } \\
4 \text { times participation } \\
\text { at World Cup }\end{array}$ & $\begin{array}{l}\text { B licence coach, } \\
\text { coaching practice of } \\
\text { min. } 6 \text { years or min. } 8 \\
\text { years of competition } \\
\text { activity - participa- } \\
\text { tion at World cham- } \\
\text { pionships (adults) }\end{array}$ \\
\hline Education & & & $\begin{array}{l}\text { Completed secondary } \\
\text { education including } \\
\text { the school-leaving } \\
\text { exam or over } 50 \text { hours } \\
\text { of the general educa- } \\
\text { tion programme at } \\
\text { the Training School } \\
\text { FPES }\end{array}$ & $\begin{array}{l}\text { Completed secondary } \\
\text { education including } \\
\text { the school-leaving } \\
\text { exam at min. }\end{array}$ \\
\hline
\end{tabular}




\section{A licence coach}

The highest qualification in fencing in the Czech Republic is A licence coach. It is provided in collaboration between the Faculty of Physical Education and Sport (FPES) at Charles University and the Czech Fencing Federation (CFF). The FPES provides the teaching of theoretical subjects based on accreditation of the Ministry of Education, Youth and Sports Czech Republic from 12th-13th May 1993 and the re-accreditation 14 756/2009 - 30/1 (https://ftvs.cuni.cz/FTVS-2198version1-organizacni_studijni_a_zkusebni_rad_ts.pdf). The second stage of the process of coach education, the specialisation ${ }^{2}$ is provided by the CFF. The study at the Coaching School at FPES is conceived as a form of lifelong learning (professional education, obtaining the qualification of a professional in education as stated in the law No 563/2004 Sb., $\$ 10-\$ 21$ ).

To be admitted for studies, the applicants must be over 18 years of age and must supply a valid certificate of completed vocational or general secondary education, or higher education (min. the school-leaving exam). They also need to be admitted by the respective sport federation which will provide the specialised courses.

The study programme at the coaching school (CS) is divided into 2 years (4 semesters), typically there are 9 consultations every school year on Fridays or Saturdays. The time allocation for the complete study is 500 lessons, out of which, in the new programme design, 220 lessons are devoted to the fencing specialisation (73 lessons of theory, 147 lessons of practice). Although the courses are run by the university, the graduates of the courses do not receive a bachelor degree (BSc). Upon request, however, this education allows them to obtain a trade licence. After completing all their study duties (credits and exams) and passing the final examination in front of a committee, the students receive a certificate of graduation from the CS. The students receive study materials in the form of PowerPoint presentations from individual instructors, comprehensive learning materials (Jansa \& Dovalil, 2007) or a textbook on physiology for the CS (Kohlíková 2004).

2 The content of the study for A licence was designed within the project "Trenéri do lavic" (Coaches Going Back to School) commenced from the academic year 2020/2021 by Fridrich Földes, a renowned fencing coach, formerly also the national team coach of the Czechoslovak and Czech Republic, since 1999 the head coach of the national pentathlon team of Great Britain. His students were participants and medallists at world, European championships and the Olympics.

The specialisation content:

1st year - 1st semester, the basic module: history of fencing ( 2 lessons of theory/0 practice); nomenclature and terminology (2/0); educational-psychological aspects of the coach's / instructor's work (2/0); rules of fencing (4/2); forms of work, organisation of training (2/0); methods of providing information (1/0); structure of the sports performance of fencers (3/0); basics of sports training (3/0); fencing and movement skills (4/4); fitness training of fencers $(2 / 6)$.

2nd semester, technical module characteristics of fencing technique, composition and structure (1/2); preparation exercises for technique training (2/4); technique and training of positions (1/3); technique and training of fencing guard, weapon holding (1/2); single and compound footwork - description and training of technique (1/5); footwork training (1/3); types of distances in fencing, training of distance (1/3); blade work, preparation movements (1/3); body thrusts , cuts, types of thrusts and cuts (1/4); actions without the blade, direct thrusts and cuts, disengage (1/4); types of feints (1/2); blade actions -beats, engagement, transfer (1/4); first intention attacks (1/3); second intention attacks (1/4). Defensive actions: types of defence (2/3); hand and blade positions, parries (1/4); defensive systems (1/4).

2nd year - 3rd semester, tactical module: the notion of tactics, tactical thinking (2/4); introduction to tactics (2/6); training of tactical variants within technical preparation (3/12); Module of guiding an athlete in a competition and analytical work of the coach: guiding an athlete through a competition (2/4); the writing of fencing (2/0); long-term monitoring of an athlete and opponents $(2 / 0)$.

4th semester, specialisation: specifics of fencing training: distance, types of trusts and cuts (1/4); individual lessons 1 (3/12); individual lessons 2 (3/12); forms of technical preparation: pairs exercises, dummy exercises $(2 / 6)$; analysis and correction of errors (2/10). 
The final examination at the CS consists of an oral exam from the specialisation and theory. Another part of the final examination is the defence of the thesis on an assigned or chosen topic (min. 30 pages according to the given parameters: https://is.cuni.cz/studium/ekczv/index. php?do=detail\&cid=6482; https://ftvs.cuni.cz/FTVS-2198.html). The practical part of the examination is held in a fencing hall. The fees charged for the study at the CS A licence (the theoretical part) are 11 thousand CZK for 2020/2021 or 13 thousand CZK for $2^{\text {nd }}$ year students (https://ftvs. cuni.cz/FTVS-2198.html).

\section{B licence coach}

The second highest level of formal education in the qualification process of the CFF is the B licence. Similarly to the A licence, education is provided in collaboration with the Coaching School FPES and CFF. The general part of the training course, the so-called Scientific Basis of Sports Training is provided by the FPES CU, the specialisation traditionally by the CFF. The Coaching School runs the programme as a part of lifelong learning - vocational training as specified in the Czech legislation. The study programme is divided into the general and specialised part, in this case theory and practice. There are 50 lessons of the "scientific basis" at the FPES and 100 lessons of specialisation provided by the respective sport federations. For applicants who have not completed secondary education, including the school-leaving exam, there is an obligation to complete 50 lessons of the basic general programme. The theoretical lessons are held during 2 weekend consultations (from Friday - Sunday). The registration procedure is similar to the A licence. The applicant needs to supply a certificate of the highest education received and the CFF then sends the form to the Lifelong Learning Centre of the FPES CU.

The final examination at the Coaching School for B licence coaches consists of a written test on the subject matter covered in the Scientific Basis of Sports Training and taught during the weekend consultations. The final written dissertation has min. 15 standardised pages and there are theoretical and practical examinations from the specialisation. At the enrollment, students receive study materials, however, these have not always been a regular part of the study support (Perič, 2016). In terms of content, the text focuses on topics taught in the lessons of the CS: anatomy, kinesiology, physiology, physiology of training load, sports psychology, educational science (including Fair play), sports training (including sports training in children), compensation exercise, nutrition, first aid, management and basics of doping prevention.

\section{C licence Coach}

The education of $\mathrm{C}$ licence coaches is provided solely by the CFF and its staff who are the Education and Methodology Committee (EMC) instructors for individual specialisations (weapons). In total, there are 30 theoretical and practical classes. Study materials are provided to the course attendees electronically as PDF documents or PowerPoint presentations and are usually designed by the instructors. The materials also include videos supplementing the lectures dealing with theory and practice of fencing, however, these are currently accessible only to the course participants. The theoretical block of sessions consists of 13.5 classes. ${ }^{3}$ The process of innovation of C licence coaches' training started before 2020 in the specialisation of foil. The training was provided by the club of sport fencing TJ Sokol Bystřice nad Pernštejnem since 2017 with their

3 In the theoretical part, the lessons include topics concerning the basics of anatomy and physiology of training (1 lesson of theory / 0 practice); physiology of loading (1/0); theory of sports training (1/0); hygienics and load compensation (1/0); pedagogical basics of training (1/0); sport preparation of children (1/0); definition of the term coach and using soft skills in their practice (1/0). From the specialisation part, the students of the course are partly introduced to the following topics: fencing history $(1 / 0)$; fencing - sports performance structure $(1 / 0)$; fencing - basics of technique (1/0); overview of types of fencing actions (1/0); positions and fencing footwork (1/0); basics of the technical training of fencers (1/0); history of fencing rules $(0,5 / 0)$. 
successful and experienced coaches. Since 2020, the foil specialisation is linked to the unified system of coach education under the patronage of the EMC.

The final examination for $\mathrm{C}$ licence coaches consists of a written test covering the subject matter of the theoretical lectures and specialisation. A practical examination from the chosen specialisation (foil, sabre, épée) is also a part of the assessment. The course run by the CFF is free of charge.

\section{Instructor}

The instructor is the lowest introductory degree in the process of formal coach education of the CFF. It comprises 12 practical and theoretical lessons. There is also the lowest entrance age level (upon turning 16). The only course completion requirement is attendance or a final test. Similarly to the other levels, the course attendees receive study materials such as presentations and video materials. The training run by the CFF is free of charge.

\section{The system of training and in-service workshops by the CFF}

Apart from the continuing formal education of coaches, the CFF also runs training and weekend workshops on chosen topics or invites guests from within and outside the institution. In the course of the Olympic cycle, the federation holds a specialised workshop under the supervision of a foreign expert for all the specialisations. In addition, the CFF organises workshops for inservice coaches in collaboration with the EMC. These are a compulsory part of the upgrade of a valid licence in a 5 -year cycle.

It is the duty of coaches and instructors to complete at least two of the given options specified in Table 2. After that, the licence is automatically renewed. If they fail to do so, their license can be revoked. These partial tasks primarily entail continuous practice and participation in seminars. By means of these measures, the CFF aims to ensure the continuing and systematic education of its coaches (https://www.czechfencing.cz/uploads/documents/119.pdf).

Table 2. The system of in-service workshops for coaches provided by the CFF

\begin{tabular}{llll}
\hline Instructor & C licence coach & B licence coach & A licence coach \\
\hline $\begin{array}{l}2 \text { in-service seminars } \\
\text { in the course of } 5 \\
\text { years }\end{array}$ & $\begin{array}{l}2 \text { in-service seminars in the } \\
\text { course of 5 years }\end{array}$ & $\begin{array}{l}2 \text { in-service seminars in the } \\
\text { course of 5 years }\end{array}$ & $\begin{array}{l}1 \text { in-service seminar in the } \\
\text { course of 5 years }\end{array}$ \\
\hline $\begin{array}{l}\text { Active as an instruc- } \\
\text { tor }\end{array}$ & Active as a coach & Active as a coach & Active as a coach \\
\hline & $\begin{array}{l}\text { Must participate in the } \\
\text { training of new instructors } \\
\text { or coaches }\end{array}$ & $\begin{array}{l}\text { Must participate in the } \\
\text { training of new instructors } \\
\text { or coaches }\end{array}$ \\
\hline & $\begin{array}{l}\text { Must participate in an } \\
\text { international seminar }\end{array}$ & $\begin{array}{l}\text { Must participate in an } \\
\text { international seminar }\end{array}$ \\
\hline & & $\begin{array}{l}\text { Preparation or realisation } \\
\text { of training - in-service } \\
\text { training of lower-licence } \\
\text { coaches }\end{array}$ \\
\hline
\end{tabular}

\section{The system of fencing coach education in Great Britain}

Britain founded its own national fencing federation in 1902 under the name Amateur Fencing Association - AFA with Alfred Hutton, the author of a famous textbook on fencing (Hutton, 1889) as its head. AFA was renamed in 1996 the British Fencing Association - BFA and has been using 
the name with British Fencing - $B F$ ever since. The $B F^{4}$ is responsible not only for the traditional agenda of the federation but also for fencing coach education and it is the technical guarantor. Apart from the above given $\mathrm{BF}$ as an umbrella organisation on the international fencing scene, fencing training is managed and organised based on the administrative division: England, Wales, Scotland and Northern Ireland. Each of the countries has its own fencing federation which organises its own regional competitions and championships and takes part in British championships under the patronage of the BF. Every four years the national teams also take part in the Commonwealth Games (Kirby, 2014).

The system of fencing coach education in Great Britain reflects regional interests and partly the pursuit of independence presents an issue. A typical example is Scotland where they developed their own 5-level system of coach education which is completely independent of the BF programme of fencing coach education as represented by the British Fencing Coaching Framework - BFCF $F^{5}$. Welsh Fencing - WF has a partly independent system close to the BFCF. The only exception in the Welsh Federation is the foundation training of the coaches of the lowest levels, specifically the programmes Introduction to Coaching Fencing (L1) a Coaching Fencing (L2), provided by the WF itself (https://www.welshfencing.org/index.php/component/content/article/10coaching/650-coaching-system?Itemid=101). The courses for coaches are run on regional level using various locations and sports facilities to allow the access for applicants from all over Wales. Like other BF institutions, WF also hires external collaborators to enhance the quality of teaching in areas such as fitness training of fencers, sports psychology, nutrition, etc.

The British Academy of Fencing - BAF was formed as a professional alternative to the existing AFA (today's BF). Since its foundation in 1948 (with the separation period between 1998 and 2018), it has played a role in the systematic education of masters, coaches and instructors of modern sports fencing. The BAF system of education includes five levels: Level 1, Level 2, Level 3 (Moniteur), conceived as introductory levels and the so-called advanced degree Level 4 (Prevot) and the highest level - Level 5 (Diploma). The graduates of BAF programmes are recognised abroad thanks to the organisation's links to Academie d'Armes Internationale - http://www.aai.world/. It is important to note that the organisation together with the Academie d'Armes Internationale does not set the trends any more in modern fencing coach education. There was an ideological split in 1998 between BAF and BF. However, since 2018, there has been a shift in the perception of BAF and after improved standards in teaching, its graduates are once again recognised by the $\mathrm{BF}^{6}$ (British Academy of Fencing, 2020). In Great Britain, the British Fencing is the main organisation educating fencing coaches with significant international achievements although paradoxically, the British Academy of Fencing remains the only organisation operating nation-wide (Kirby, 2014, p. 4).

British Fencing has also struggled with results in the past. Those were achieved mainly thanks to "imported experts" - coaches. The efforts to improve the quality of fencing coach education led to the implementation of Coach Development Project in 2007. The project was introduced into the BF structures as a pilot programme designed on the basis of research. It assessed the current situation and gave clear recommendations as to in which direction the development of fencing in Britain should go. This project was seen as ground-breaking and because of its scope belongs to the outstanding events of the BF (Randall, 2009). During the design, questions addressing coach education in fencing specialisation as well as other issues were addressed.

\footnotetext{
4 For the sake of simplicity in the text we refer to it as BF-British Fencing

5 https://www.britishfencing.com/members/coaching-zone/the-bf-coaching-framework/

6 https://baf-fencing.com/the-baf-and-british-fencing/
} 


\section{Fencing coach education in England, Northern Ireland, and Wales}

In terms of coach education, the fencing federations of England, Northern Ireland, and Wales are currently following the strategic document British Fencing Coaching Framework (British Fencing Coaching Development Framework, 2017, p. 20-21) which outlines the organisational, curricular and ideological framework of the process of improving the coaching competences of the BF members. This framework was designed to improve the coaching skills of every applicant and puts an emphasis on the modern approach in catering for specific needs of coaches (Trudel \& Gilbert, 2006). This is reflected in areas such as providing support on the community level, teachers' work at school to integrate fencing into their syllabi, improving the managerial and communication skills but also in performance and elite sport.

The system does not specify only the levels of coach education but also its philosophy which includes four main points: 1 / the Culture of Learning - the striving for permanent development of competences of the coaching community; 2/ the approach of Continuous Improvement based on the reflection of coaching practice; 3 / the option of Flexible Modules in coach education; 4/ appreciation and recognition of coaches' work not only on elite but on all levels (Coaches are valued $)^{7}$.

Another approach, not very common in sport, is emphasising the understanding of the process of professional growth in the system of Why? How? and What? to do. We commonly encounter the paradigm "show and copy", which is represented by the adverbs "why" and "how", however, the part that would refer to the philosophical essence of individual elements and their integration into the subject matter is often missing.

Those interested in systematic coaching education are guided by the information and links on the website in the section Coaching zone to individual options that the system enables (https:// www.britishfencing.com/members/coaching-zone/).

Among the duties of coaches, assistants and other staff in sports organisations, there is the completion of a course Safeguarding \& Protecting Children ${ }^{8}$, training of first aid and the submission of a criminal record check. In the area of children protection, there are mandatory retrainings to be taken every three years at minimum. This specific course aims to maximise the protection of athletes, prevent abuse and provide a safe environment for training. It also attempts to minimise the risks of potential lawsuits. The course covers issues that are important in the Czech context, however, so far not as much attention has been paid to them as in the Anglo-Saxon world (the issues of sexual abuse, equal opportunities, racial discrimination, etc.).

Similar measures are applied also in sport in the USA where the issues are dealt with by the organisation the U.S. Center for SafeSport. ${ }^{9}$

The system of coach education is conceived on several levels and is described as the Coach's Journey (https://www.britishfencing.com/members/coaching-zone/the-bf-coaching-framework/ my-coachs-journey/). The name itself refers to the dynamics in the conception of professional development of assistants and coaches of fencing based on the philosophy of the BF system. The long-term continuous development - similarly to the generally accepted professional development model beginner $\rightarrow$ expert of the Dreyfus brothers (Dreyfus \& Dreyfus, 1980).

\footnotetext{
https://www.britishfencing.com/members/coaching-zone/the-bf-coaching-framework/

8 ttps://www.britishfencing.com/bf-online-renewal-safeguarding-protecting-children-course-fencing-specific/

9 https://uscenterforsafesport.org/
} 


\section{Core Coach $^{10}$}

The introductory course Core Coach is aimed at those applicants who do not necessarily have direct experience of fencing, however, they wish to participate in the training sessions and fencing competitions as well as other events associated with fencing. Teaching is aimed at the mastering of the most basic skills of beginners or presentation of fencing ${ }^{11}$. Depending on the level of experience of the attendees, the time allocation varies between 1-2 days or 6-12 topics. If the applicants have had no previous experience with the organisation of sports events or have not completed any other formal education in sport, they participate in the longer variant of the training.

The prerequisite for enrolling on the course is the min. age limit of 18 years and a valid certificate of the Safeguarding \& Protecting Children as well as a First Aid course. Furthermore, the applicant must submit a criminal record check. The fee for the course is 20 GBP.

\section{Introduction to Coaching Fencing (L1) ${ }^{12}$}

The course L1 is aimed at applicants with previous experience with fencing who wish to participate in the training process as assistant coaches or coaches or at those who wish to work in the fencing community without the ambition of becoming a coach. The taught actions are focused on the mastery of designing training for a specific training group and the development of coaching skills in fencing. ${ }^{13}$ On the "how?" level, the syllabus of the course focuses on the usage of voice and coaching signals in fencing training. The process skills such as instructions, demonstration, observation and feedback in coach's work, KLPs - Key Learning Points are trained.

The syllabus of the course also aims to introduce the importance of self-reflection on one's coaching practice and methods employed. From the specialisation the significance of distance, timing and presentation of the coach's blade in weapon training is highlighted. A newly introduced topic as compared to the Core Coach course is the issue of guiding the athletes, types of coaching style and the focus on the knowledge and interpretation of the rules of fencing. In comparison, the knowledge of the rules of fencing features in the CFF coach education in the syllabi of higher levels (A Licence 4 lessons of theory / 2 lessons of practice). Other than that there are self-standing trainings for fencing referees under the patronage of the CFF. The conditions for getting accepted are the same as for the introductory course of the BF, that is a valid Safeguarding $\&$ Protecting Children certification, a First Aid training and a criminal record check. Furthermore, the applicant must provide evidence of personal active experience of fencing of min. one year. The min. age limit is 16 provided there are positive references. A valid membership in the BF is essential as well. The time allocation is 20 theoretical and practical lessons. There are study materials for the course, however, they are not freely available.

\footnotetext{
${ }^{10} \mathrm{https} / /$ www.britishfencing.com/members/coaching-zone/the-bf-coaching-framework/my-coachs-journey/ core-coach-offer/core-coach-course-overview/

11 Organisation of a training group: planning; voice technique; coaching signals. Rhythm, strength, speed - their training and instruction in fencing. Conducting a training session and teaching by means of process skills: instruction, demonstration, observation and feedback. The technique of KLPs (Key Learning Points). The ability to recognise and correct mistakes in the basic fencing technique (guard, lunge, etc.). Ethics of fencing, holding and manipulation of weapon, step forward - step backward, rules of weapons (foil and sabre). Introduction to the social environment in fencing training. From the attack actions the teaching includes a combination of actions: lunge attack, defence - parry and riposte, counter riposte.

${ }^{12}$ https://www.britishfencing.com/members/coaching-zone/the-bf-coaching-framework/my-coachs-journey/ introduction-to-coaching-fencing/

13 The development of basic fencing skills (weapon holding, on guard position, armed arm position, touches, parries, footwork technique- step forward, step back, lunge, step-lunge, recovery); attack; defence; 1st counter riposte; preparations of fencing actions; movement skills facilitating the development of fencing actions; basic rules of fencing; understanding the essence of fencing.
} 


\section{Coaching Fencing Course (L2) ${ }^{14}$}

Another level of formal coach education at the BF is the L2 course focused on the professional development of coaches working in clubs with fencers who take part in domestic tournaments. In terms of the content, the attendees develop their knowledge of issues dealing with setting and planning goals. Next, the subject matter expands from the original topic of group sessions to individual work, in particular it deals with the topic of the design and composition of individual lessons. The specialised study focuses only on one weapon. Other coaching competences are developed, namely the process, technical and tactical skills of coaches. The topics of the previous course are expanded in the sense that the new topics touch upon the teaching of compound actions, stop hits, renewals, preparations of attacks, etc. ${ }^{15}$ The conditions for being accepted are similar to those on the lower level as shown in table 3 . The course includes theoretical and practical classes amounting to the total of 35 lessons (a 4-day course). The course has study materials which are not freely available.

\section{The Weapon Specific Courses L3 a L4 ${ }^{16}$}

The Weapon Specific Courses L3 and L4 are programmes aimed at coaches and head coaches of clubs whose athletes regularly participate in official international competitions (European Cadet Circuit, JWC). The coaching course focuses on teaching and the acquisition of processes associated with effective coaching of group and individual session in the broader tactical and technical context ${ }^{17}$. From the épée specialisation, the focus is e.g. on the methodology of the leg and foot hits. In the L3 degree, the course focuses on the development and guidance in the attendees' coaching philosophy and improvement of their analytical abilities by means of a tool called Training Needs Analysis which helps identify and improve the set goals. Also, the emphasis is on self-reflection on the coaching practice. On L4 level, the attendees have to submit training session plans, a presentation on the technical aspects of a chosen weapon and design a training plan for the present season. The course is focused on the design and implementation of individual lessons. All these partial tasks stress the analytical and planning aspect in coach's work and its importance for achieving a higher sports level.

\footnotetext{
14 https://www.britishfencing.com/members/coaching-zone/the-bf-coaching-framework/my-coachs-journey/ coaching-fencing-course-12/

15 The planning of individual sessions and specifically targeted group sessions (focused on a certain topic); conducting training sessions using advanced process skills: instruction, explanation, demonstration, using observation and feedback in the process of motor learning and training; blade presentation, perception refinement and using specific means to train distance, timing and rhythm.

16 https://www.britishfencing.com/members/coaching-zone/the-bf-coaching-framework/my-coachs-journey/ weapon-specific-course-13/; https:/www.britishfencing.com/members/coaching-zone/the-bf-coaching-framework/my-coachs-journey/weapon-specific-course-14/

17 Opposition offensive actions angulated offensive actions, point in a line, prise defers, opposition parries, compound counter-attacks and counter riposte, close quarters, flicks in foil and épée, all footwork preparations, all blade presentations. Next, it is renewals, compound attacks, simultaneous attacks and the above-mentioned flicks at the opponent's leg in épée.
} 
Table 3. BF course structure

\begin{tabular}{|c|c|c|c|c|c|}
\hline & Core Coach & $\begin{array}{l}\text { Introduction } \\
\text { to Coaching } \\
\text { Fencing (L1) }\end{array}$ & $\begin{array}{l}\text { Coaching } \\
\text { Fencing (L2) }\end{array}$ & $\begin{array}{l}\text { Weapon } \\
\text { Specific (L3) }\end{array}$ & $\begin{array}{l}\text { Weapon } \\
\text { Specific (L4) }\end{array}$ \\
\hline Time allocation & $\begin{array}{l}\text { Depending } \\
\text { on the level of } \\
\text { experience } \\
1-2 \text { day (6-12 } \\
\text { modules). }\end{array}$ & $\begin{array}{l}2 \text { days (16 les- } \\
\text { sons) } \\
\text { of direct teach- } \\
\text { ing }+4 \text { lessons } \\
\text { of self-study, } 20 \\
\text { lessons in total }\end{array}$ & $\begin{array}{l}4 \text { days of train- } \\
\text { ing (32) lessons } \\
\text { of direct teach- } \\
\text { ing }+3 \text { lessons } \\
\text { of self-study, } 35 \\
\text { lessons in total }\end{array}$ & $\begin{array}{l}5 \text { days ( } 35 \text { les- } \\
\text { sons) of direct } \\
\text { teaching }+5 \\
\text { lessons of self- } \\
\text { study, } 40 \text { lessons } \\
\text { in total }\end{array}$ & $\begin{array}{l}2 \text { days (16 les- } \\
\text { sons) }\end{array}$ \\
\hline Age limit & $>18$ years & $\begin{array}{l}>18 \text { years (ex- } \\
\text { ceptions granted } \\
\text { based on a refer- } \\
\text { ence to }>16 \text { let) }\end{array}$ & $>18$ years & $>18$ years & $>18$ years \\
\hline $\begin{array}{l}\text { Qualification } \\
\text { prerequisites } \\
\text { (fencing experi- } \\
\text { ence) }\end{array}$ & $\begin{array}{l}\text { Safeguarding } \\
\text { \& Protecting } \\
\text { Children, first } \\
\text { aid training, } \\
\text { criminal record } \\
\text { check }\end{array}$ & $\begin{array}{l}\text { Safeguarding } \\
\text { \& Protecting } \\
\text { Children, first } \\
\text { aid training, } \\
\text { criminal record } \\
\text { check } \\
\text { Fencing experi- } \\
\text { ence > 1 year, } \\
\text { valid member- } \\
\text { ship in the BF }\end{array}$ & $\begin{array}{l}\text { Safeguarding } \\
\text { \& Protecting } \\
\text { Children, first } \\
\text { aid train- } \\
\text { ing, criminal } \\
\text { record check A } \\
\text { holder of the } \\
\text { Introduction } \\
\text { to Coaching } \\
\text { Fencing (L1) or } \\
\text { older version } \\
\text { (BF L2 before } \\
\text { 2016), valid } \\
\text { membership in } \\
\text { the BF }\end{array}$ & $\begin{array}{l}\text { Safeguarding } \\
\text { \& Protecting } \\
\text { Children, first } \\
\text { aid training, } \\
\text { criminal record } \\
\text { check. A holder } \\
\text { of Coaching } \\
\text { Fencing (L2) ort } \\
\text { he older version } \\
\text { (BF L3 before } \\
\text { 2016), valid } \\
\text { membership in } \\
\text { the BF }\end{array}$ & $\begin{array}{l}\text { Safeguarding } \\
\text { \& Protecting } \\
\text { Children, first } \\
\text { aid training, } \\
\text { criminal record } \\
\text { check. Holder of } \\
\text { Weapon Specific } \\
\text { (L3) o ran older } \\
\text { version (BF L4 } \\
\text { before } 2016) \text {, } \\
\text { valid member- } \\
\text { ship in the BF }\end{array}$ \\
\hline Education & not stated & not stated & not stated & not stated & not stated \\
\hline
\end{tabular}

The time allocation in L3 is 5 days (35 lessons) of direct teaching for the L3 +5 lessons of self-study while in the L4 programme there are 2 days (16 lessons). The prerequisites for participation are similar to the two previous courses (see Tab. 3), in addition, there is an obligation to submit the given assignments.

\section{Education of fencing coaches in Scotland}

The education of coaches in Scotland is provided by an independent system which is, nevertheless, valid for the fencing coaching practice all around Great Britain and vice versa. The formation of an autonomous organisational entity of Scottish fencing began in 1923 with the establishment of the Scottish Amateur Fencing Union - SAFU. The current Scottish Fencing - SF (http://www. scottish-fencing.co.uk/) is an autonomous organisation in terms of internal affairs, it is, however, represented by the umbrella organ of British Fencing, the BF on international level. The beginnings of coach education in Scotland are closely linked to the name Bert Bracewell who was in the '60s of the last century appointed the national fencing coach and started to build a system of coach education provided by means of the National Coaching Scheme. Later, the Scottish Coaches Association (1969) was founded. Gradually, two levels of fencing coaching education were developed, namely the Basic Coaching Certificate (1967) and also the Intermediate Coaching Certificate in 1970 (Beaumont, 1966; Gray \& Cohen, 1984). At the moment, the education of fencing coaches is provided by the Scottish Fencing Coach Programme (https://www.sfcoach.co.uk/), which developed and implements a five-level system of coach education. 


\section{L.1 Volunteer Coach ${ }^{18}$}

The starting level of formal fencing coach education in Scotland is the L1 - Volunteer Coach, composed primarily of modules dealing with creating a safe space for training - Safe. Another important topic is setting the code of conduct for training sessions and for the sports community in general. Course attendees are also acquainted with the Scottish Fencing Code of Conduct for Safeguarding Children in Sport. ${ }^{19}$ It includes examples of good practice (sport as fun, the promotion of fair play, constructive feedback, relationships built on trust) as well as situations that coaches should avoid or are completely unacceptable (favouritism, excessive amount of time spent with a child alone, unauthorised entry into the trainees' rooms, sexual innuendoes, mental abuse, sharing a room with a trainee at a sports event, etc.).

The second module is Teach the Game in which the principles of Teaching games for understanding - TGfU (Werner, Thorpe, \& Bunker, 1996) are applied to teach fencing skills such as attack and defence. The module Well Run deals with providing information and practical skills in training planning, the use of entertaining aids and creating a positive and inspiring environment for training. The last module is Inclusive, aimed at planning activities and procedures that help cater for the needs of the trainees, coach's integrity, the ways to avoid and prevent abuse including the completion of the Safeguarding Course ${ }^{20}$.

The final requirements include the planning and implementation of six fencing lessons. The courses provide freely accessible study materials and references to individual study areas. ${ }^{21}$ Some of the materials were provided by the umbrella organisation of Scottish sport - Sportscotland, an equivalent of the Czech National Sports Agency - NSA.

\section{L.2 Community Coach ${ }^{22}$}

The second SF course is called the Community Coach. It focuses on specific aspects of fencing such as the perception of distance, timing and fencing tactic. To improve these skills, the models REFLECT and EQ are used, where emotional intelligence is applied to optimise decision making in a fencing fight by means of connecting thinking and feeling (Gobinder, 2014). The models are used to improve the quality of control over maintaining the distance and timing of the actions of fencers. Both these skills are key to success in fencing. Another topic of the course is the conception of fencing bouts by limiting the tactical and technical possibilities of fencers - Constraint-led. The constraint or the inverse setting of options available to a fencer strengthens the focus on specific aspects of movement stereotypes and their effective transfer to competition scenarios. A Czechoslovak author dealing with the phenomenon was e.g. Bořivoj Bidlo (1975).

\footnotetext{
${ }^{18}$ https://cd8cee83-81ef-442d-b657-0b93af851eba.filesusr.com/ugd/830e40_06e16bb0b8db4fe4a632a04af9e 3f800.pdf

${ }^{19}$ http://www.scottish-fencing.co.uk/sites/default/files/SF\%20CodeofConduct_0.doc. Scottish Fencing Code of Conduct for Safeguarding Children in Sport. The students are also acquainted with the protection policy of the $B F$.

${ }^{20}$ The study and subsequent completion of the e-learning course Child Wellbeing and Protection in Sport (https:// sportscotland.info/childwellbeing/v4/index.html)

${ }^{21}$ https://www.sfcoach.co.uk/level-3

${ }^{22}$ https://cd8cee83-81ef-442d-b657-0b93af851eba.filesusr.com/ugd/830e40_3013212cc85346a7b5a6c7ef4f885 eb1.pdf
} 


\section{L.3 Club Coach ${ }^{23}$}

The programme Club Coach focuses on the mastery of processes dealing with competitiveness in sport - Coaching competitiveness. The training therefore aims at procedures that make training more effective and help fencers achieve their best possible performance. Coaches learn techniques such as observation thanks to which they are able to use self-reflection more effectively, listen to other people and focus their observation on important phenomena. Another topic is analysis where the course attendees learn to use tools such as the SWOT analysis and also become acquainted with the SFCP programme - Solution Focused Coaching Programme. ${ }^{24}$ Tactical awareness, information analysis (video analysis) and problem solution are a part of the section called Identify.

The specialisation module of training - Train provides information and methodology of training tactical sessions. Based on the description of typical examples of the coaching practice of the students (how they prepare for a training session, what information sources they use in the preparation and where they see their limits) the instructors give feedback and correction. The students then have to apply the newly acquired knowledge on three of their trainees and thus optimise the physical, mental and fencing preparation for a competition. Online material for the course is available on the web OpenLearn (https://www.open.edu/openlearn/) - Exploring sport coaching and psychology. ${ }^{25}$

\section{L.4 Talent Coach $^{26}$}

The fourth level focuses on the development of the club and team spirit. An integral part of the content on this level is the module Mindset Skills - the training of mental skills such as mental resilience, motivation, self-control, commitment and problem solving. The course also includes information on the strategies for team psychoanalysis and the design of a plan of individual mental training and its monitoring for 12-18 months (our source, however, gave the information it was 6 months rather than the official figure). In other words, the course aims at one of the most important components of the fencing performance, i.e. the mental readiness for combat or in combat. It is claimed that the mental part constitutes up to $40.7 \%$ of the performance (Kogler, 2005, p. 266).

In the area of tactical skills, the students learn how fencing fights are won and how to monitor the tactical development of the trainees. The course deals with the issue of planning - Planning Skills, which concerns the strategic planning and development of a club as well as a competition plan of individual athletes and its evaluation. The course applicants also take part in four weekends of the course SFCP, which develops the skills acquired in L3 course where the covered subject matter is demonstrated in practical conditions, and lessons designed by the applicants are demonstrated. This should give feedback as to what the students have learnt during the course and in case of ambiguity or inaccuracy, the educators provide them with correction. The course also includes the online course of the platform OpenLearn dealing with eating habits of athletes - Eating to Win. ${ }^{27}$

\footnotetext{
${ }^{23}$ https://cd8cee83-81ef-442d-b657-0b93af851eba.filesusr.com/ugd/830e40_a54cbef4f94a4209920ef184f34f9232. pdf

${ }^{24}$ SFCP Coaching Process (Teach Game $\rightarrow$ Coach distance and timing $\rightarrow$ Facilitate competitive scenarios $\rightarrow$ Talent Development $\rightarrow$ High Performance).

${ }^{25}$ https://www.open.edu/openlearn/health-sports-psychology/exploring-sport-coaching-and-psychology/content-section-overview?active-tab=description-tab

${ }^{26}$ https://cd8cee83-81ef-442d-b657-0b93af851eba.filesusr.com/ugd/830e40_b56433d4764b4d6b94986be46a13d935. pdf

${ }^{27} \mathrm{https} / /$ www.open.edu/openlearn/health-sports-psychology/sport-fitness/eating-win-activity-diet-and-weightcontrol/content-section- 0 ? active-tab $=$ description - tab
} 


\section{L.5 Performance Coach $^{28}$}

The ultimate level in the system of fencing coach education in Scotland is the course L5 Performance Coach. The aim of the course is to provide the students with support on elite technical and tactical level. The syllabi of the courses state that the coach's level is as high as to make it possible for the trainees to achieve the ranking among the 32 best competitors in the official FIE and EFC tournaments. The coaches develop their own coaching philosophy, inspire and provide mentoring to other coaches. The attendees are required to successfully complete the online course Motivation and factors affecting motivation. ${ }^{29}$

Next, they learn to use specific tools for goal setting and problem solving, e.g. the active application of the GROW model ${ }^{30}$ (Whitmore, 2009), both on themselves and their trainees. Another tool the attendees learn to apply in the area of assessment and personal and process goal setting is the popular SMART tool. The distance learning platform OpenLearn is further used in the area of training management - specifically with regard to the topic of recovery after training load. ${ }^{31}$

To conclude the section on the Scottish system of fencing coach education, let us add that the time allocation of courses is not strictly given. It is stated only approximately and can be adjusted depending on the knowledge, understanding and grasp of the covered subject matter. Generally speaking, the SF courses run mostly at weekends on Saturdays and Sundays during two teaching blocks - morning and afternoon one with an hour lunch break. There are 7 lessons daily. The legal conditions that Scottish coaches need to comply with are the same as the ones for courses run by the BF. L1 course is open to applicants older than 16 whereas the other courses are for applicants over 18.

The allotted time is one weekend if the attendees have previous experience. In other instances the length of the course can be extended up to 3 weekends depending on the experience and current competences of the students. This open format applies also to L2 courses (2-4 weekends) and L3, where the length varies between 3-6 weekends. L4 and L5 are very specific both in terms of content and time allocation.

The applicant on L4 level has to complete the set assignments for min. 6 months (the syllabi of the course give 12-18 months) while working with their trainees. The situation is similar in the highest L5 level, however, the time allocation is not specified ${ }^{32}$. The price of coaching courses varies from $60 \mathrm{GBP}$ for the L1 course to 120 and $180 \mathrm{GBP}$ for L2 and L3 respectively (http://www. scottish-fencing.co.uk/calendar/2019/01/19/coach-education-11-12-13-and-plastic).

\footnotetext{
${ }^{28}$ https://cd8cee83-81ef-442d-b657-0b93af851eba.filesusr.com/ugd/830e40_00dc59d1c5ff4cec89d00ece5b0b5 a4e.pdf

29 ttps://www.open.edu/openlearn/health-sports-psychology/motivation-and-factors-affecting-motivation/ content-section- 0 ? intro $=1$

${ }^{30}$ The method of goal setting and problem solving ( G - Goal, R - Reality, O - Obstacle and Options, W - Way Forward).

${ }^{31}$ Recovery strategies in sport and exercise (https://www.open.edu/openlearn/health-sports-psychology/recovery-strategies-sport-and-exercise/content-section- 0 ?active-tab=description-tab)

32 The additional information was provided by a Scottish informant, among others a graduate of ICC and FIE Coaching Academy (foil specialization).
} 
Table 4. SF course structure

\begin{tabular}{|c|c|c|c|c|c|}
\hline & L. 1 & L. 2 & L. 3 & L. 4 & L. 5 \\
\hline $\begin{array}{l}\text { Time alloca- } \\
\text { tion }\end{array}$ & $\begin{array}{l}\text { 1-3 weekends } \\
\text { depending on } \\
\text { the level of ex- } \\
\text { perience ( } 14-42 \\
\text { lessons) }\end{array}$ & $\begin{array}{l}2-4 \text { weekends } \\
\text { depending on } \\
\text { the level of ex- } \\
\text { perience ( } 28-56 \\
\text { lessons) }\end{array}$ & $\begin{array}{l}\text { 3-6 weekends } \\
\text { depending on } \\
\text { the level of ex- } \\
\text { perience ( } 42-84 \\
\text { lessons) }\end{array}$ & $\begin{array}{l}6 \text { months } \\
\text { coaching a } \\
\text { performance- } \\
\text { focused group, } \\
\text { consults, plans } \\
\text { and teaches the } \\
\text { content of the } \\
\text { course }\end{array}$ & $\begin{array}{l}\geq 6 \text { months } \\
\text { of coaching a } \\
\text { performance- } \\
\text { focused group }\end{array}$ \\
\hline Age limit & $>16$ years & $>18$ years & $>18$ years & $>18$ years & $>18$ years \\
\hline $\begin{array}{l}\text { Qualification } \\
\text { prerequisites } \\
\text { (fencing expe- } \\
\text { rience) }\end{array}$ & $\begin{array}{l}\text { Criminal record } \\
\text { check. Other } \\
\text { duties fulfilled } \\
\text { within the } \\
\text { course } \rightarrow \text { Child } \\
\text { Wellbeing and } \\
\text { Protection in } \\
\text { Sport, First aid } \\
\text { training }\end{array}$ & $\begin{array}{l}\text { Safeguarding } \\
\text { \& Protecting } \\
\text { Children or its } \\
\text { equivalent, First } \\
\text { aid training, } \\
\text { criminal record } \\
\text { check }\end{array}$ & $\begin{array}{l}\text { Safeguarding } \\
\text { \& Protecting } \\
\text { Children or its } \\
\text { equivalent, First } \\
\text { aid training, } \\
\text { criminal record } \\
\text { check }\end{array}$ & $\begin{array}{l}\text { Completing } \\
\text { L3 course. } \\
\text { Coaching one's } \\
\text { own group of } \\
\text { performance- } \\
\text { focused fenc- } \\
\text { ers + duties } \\
\text { determined by } \\
\text { legislation }\end{array}$ & $\begin{array}{l}\text { Completing } \\
\text { L4 course. } \\
\text { Coaching one's } \\
\text { own group + } \\
\text { individuals } \\
\text { ECC, SP (up to } \\
\text { 32nd) + duties } \\
\text { determined by } \\
\text { legislation }\end{array}$ \\
\hline Education & not stated & not stated & not stated & not stated & not stated \\
\hline
\end{tabular}

\section{The Hungarian system of coach education in fencing}

An important role in the system of fencing coach education in Hungary as well as on international level is played by the University of Physical Education in Budapest Testnevelési Egyetem - TE (https://tf.hu/), which teaches combat sports since its foundation in 1952. The teaching of fencing coaches is currently provided by the Budapest sports university to three strategic partners. 1/ It provides training for domestic fencing coaches via the Hungarian Fencing Federation (Magyar Vívó Szövetség - MVSz). 2/ The second subject collaborating on fencing coach training in Hungary is the International Coaching Course - ICC. 3/ The last key partner is the FIE and its Budapest Coaching Academy.

The education of fencing coaches provided by Hungarian institutions is also aimed at foreign fencers, primarily by projects of FIE Budapest Coaching Academy and the International Coaching Course (ICC). In this paper we solely discuss the programmes of formal education aimed at Hungarian coaches of fencing.

\section{University study of fencing - bachelor programme}

The highest form of studying coaching of fencing in Hungary is a bachelor study programme at TE in Budapest, namely the field of study BA Edzö (BA Coach). ${ }^{33}$ The study is a part of the combined study programme and is not offered annually (the course will run e.g. in 2021/2022; https://hunfencing.hu/hir/vivoedz-kepzes-a-te-n-4206). The standard length of the study is 3 years ( 6 semesters) and throughout the study, the student needs to obtain 180 credits in total. The graduates of the programme can successfully plan and independently implement the training process of athletes with regard to their physical and mental well-being. They can coach athletes of different performance levels and develop their personality as well as sports performance. The

\footnotetext{
${ }^{33}$ Apart from BA programmes the university also provides bachelor programmes BSc - Rekreáció és életmód
} (Recreation and Lifestyle) and BSc - Sportszervezés (Sports organisations). 
graduate is also able to organise and realise integrated sports and leisure activities, courses, training, events and competitions. ${ }^{34}$

The applicants for the field of study coaching of fencing have to pass the entrance exams consisting of a written test on biology, then the written and oral exam from the theory of sports training. The highest score, however, is obtained for the part of the test that deals with the sports or coaching practice and tests the practical level of the respective sports discipline. Applicants with significant sports or coaching achievements in their practice so far are exempted from the entrance exams ${ }^{35}$ (ttps://tf.hu/felvetelizok-kepzeseink/ba-bsc-szakok/ba-edzo). During their studies, students also need to serve their internships (practice) ranging from 200 to 400 hours. The internships are organised in collaboration with the Hungarian Olympic Committee (Magyar Olimpiai Bizottság) and the Hungarian Fencing Federation (Magyar Vívó Szövetség).

The requirements for completing the programme are as follows: the final state exam from the theory and practice and submitting an assignment on a chosen or assigned topic including its defence (the topics of bachelor theses are posted on the web of the university: https://tf.hu/ intezetek-es-tanszekek/sportagi-intezet/kuzdosportok-tanszek/szakdolgozat-temak).

It is possible to study fencing at the TE also within a one-semester subject called Vívás (fencing) run by the Department of Martial Arts - Küzdösportok Tanszék (tf.hu/kuzdo). Students can enrol on the course after completing the prerequisite subject Küzdösportok alapjai (basics of martial arts). The lessons of fencing are taught by renowned fencers - Ákos Patócs, faculty member, the author of an internationally acclaimed and widely well received publication on the methodology of sabre training (Patócs, 2016). In the past, lessons were taught also by Dr. László Szepesi, PhD., world-class coach, educator and author of dozens of articles and publications. $\mathrm{He}$ shares his lifelong coaching experience in a publication dealing with group training of fencing (Szepesi, 2009).

The university provides the students with study materials in the form of electronic version of learning materials of all subjects posted on an e-learning portal of the TE (ttps://e-learning. $\mathrm{tf} . \mathrm{hu} /$ ). The content related to the fencing specialisation is also included in documents for subjects of the field of study BA Edzö - Sportági elmélet és gyakorlat (Sports theory and practice I. - VI.).

\section{Coaching courses of OKJ organised by the Sports University TE}

Similarly to the Coaching School in Prague, the Sports University in Budapest organises the education of coaches based on valid legislation. The training of fencing coaches and other sports specialisations is provided in terms of organisation by Továbbképzö Központ (Further Education Centre), an equivalent of the Centre of Lifelong Learning of Charles University. The education of coaches in fencing takes place on two levels. The highest formal type of non-university study is Sportedzö tanfolyam (Sports Coach). The lowest level of coach education at university is the degree Sportoktató tanfolyam (Sports Instructor).

\section{Sportedzö tanfolyam (Sports Coach)}

The course on the highest level of coach education (except for the university bachelor or master programme at the TE university) is the Sports Coach. The study is conceived as a combined programme of 1.5 years. The total time allocation is 400 hours, out of that $40 \%$ is theory and $60 \%$ is practice. Before enrolling on the programme, the applicants can have 400 hours of specialised

\footnotetext{
34 Annotation to the study programme $B A E d z$ "

35 The applicants (athletes or coaches) who came 1st to 3rd at the Olympics, world championships or European championships in their sport are exempted from the entrance exams. The system is similar for athletes or coaches coming 4 th to 6 th. Athletes or coaches who won at a national championship in their sport in the category of adults are exempted from the sport practice exam.
} 
qualification recognised. The total time allocation thus increases to 800 lessons (https://www. perfekt.hu/sportedzo-kepzes).

It is a three-semester study programme whose total time allocation is one semester shorter than the Coaching School A licence at Charles University in Prague. The lessons are organised with the help of an application in which the trainees can opt for either regular attendance of weekly lectures in a Wednesday group (17:00-20:15) or attend classes every second Saturday (8:00 - 14:40). The classes include theoretical teaching modules such as: the basics of educational science, psychology and communication; health and first aid; the theory of training and gymnastics; the basics of entrepreneurship and organisation and the subject called employability I and II dealing with the graduates' opportunities in the labour market.

The second block of lessons - Sports training is focused on theory and practice and includes subjects such as The basics of sport and coaching skills. ${ }^{36}$ Students in this block already take part in practice realised mainly in the university sports facilities. ${ }^{37}$ This part of the programme lasts 12-15 days and can be organised as continuous or intermittent practice (e.g. 4 times 3-4 days). Practical classes are taught on weekdays. The theoretical part includes the technical and tactical classes, history and other aspects of the given sports discipline (for more detail see footnote 36). The conditions for enrollment include completed secondary education with the school-leaving exam - the applicant has to submit a copy of the exam certificate; health certificate as confirmed by their general practitioner (the applicant does not have to undergo a special sports check-up); contact details (e-mail address) and a certificate from the respective sports federation declaring the competitive history of the applicant. One difference from the Coaching School in Prague is that in this case, there is no prerequisite of a lower coach education. However, if they have it, they obtain a discount of $20 \%$ ( $50 \%$ for students of the TE). The course fee is 400.000 HUF.

The course attendees can be given assignments such as presentations or attendance of certain sports events. The unpenalized absence is $20 \%$ for theoretical consultations and $10 \%$ for the practical part. The course attendees do not have a status of a student as defined by the Hungarian legislation, and to pass exams and individual modules, there is one regular and two re-sit exam dates. The organisational regulations also allow a temporary leave. All these components are similar to those at the Coaching School in Prague.

Upon completion of all eight modules (over $51 \%$ min. success rate), the attendees can sign up for the final exam OKJ which consists of a theoretical and practical part in front of a committee. Unlike at the Coaching School in Prague, there is no obligation to submit a final written dissertation. Students are provided with full study support in the form an ensured an access to the university library and access to electronic learning materials posted on an e-learning portal of the TE (ttps://e-learning.tf.hu/). The course opens for the specific discipline only if there is a sufficient number of applicants. Successful graduates receive a state-recognised certificate of sports coach of fencing and also the Europass certificate for the recognition of qualification in the EU member states and other partners.

\footnotetext{
36 The organisation and planning of training, development of the sports performance, the development of specific sports skills and abilities such as: identify and correct mistakes in the execution of movement techniques; judge and assess abilities and endurance of athletes; plan and manage sports preparation and competition of one's athletes taking into account their age and individual talents; assess sports performance of athletes; apply modern principles and methods of talent management; design training plans, manage the activities of coach assistants; organise sports events, tournaments, sports camps; conduct the organisational, financial, administrative and marketing tasks related to coach's work; organise and conduct leisure-time activities in one's sport; identify and prevent any damage potentially related to the work; if necessary provide special assistance and first aid; collaborate with other experts on physical education and paramedics.

37 The classes of fencing are conducted in a fencing hall located in the university campus, building D, $2^{\text {nd }}$ floor.
} 


\section{Sportoktató tanfolyam (Sports instructor)}

The lower degree of coach education is the level of the Sports instructor. The course is run by the TE and conceived as a one-year combined programme with the time allocation of 200 lessons. Upon graduation, the fencing instructor is prepared to teach basic technical and tactical elements of fencing and knows the rules of the sports discipline. His / Her trainees are ready to proceed to the performance level in performance sport and gradually improve their sports performance and lead a healthy lifestyle. The instructors are able to organise and run sports courses, they take part in the organisation of competitions, they can work in leisure-time centres and sports clubs. The conditions to participate are defined as follows: min. 18 years of age, completed elementary education, a medical check-up, personal details provided, a reference from the national sports federation. In the introductory sessions of the course, the knowledge of the participants can be assessed with a test (practical or oral). The total fee for the course is 280.000 HUF, the students of TE and OKJ graduates are entitled to a discount of 50 and $20 \%$ respectively. The specialised courses open only if there is a sufficient number of applicants.

Just as with the above mentioned three-semester course, the lessons are organised through an application in which the attendees can select regular weekly lectures on Wednesdays (17:00-20:15) or Saturday classes (8:00-14:40) every other week. The teaching of theoretical subjects includes teaching modules such as the course Sports coach, the difference being that the modules Employability I and II are missing. The second block of classes - Sports training includes only the subject Basics of sport. This section of classes is allotted 8-10 days and can be organised as a continuous or intermittent practice (e.g. 4 times 2-3 days). The ratio between the theoretical and practical part is $40 \%$ of theory and $60 \%$ of practice (https://szakkepesites.hu/okj/tanfolyamok/ sportoktato-a-sportag-megjelolesevel). The practical classes can be held also on weekdays. The topics of practical classes are the result of negotiation and consensus between the national federation and TF university. Having completed all five modules (success rate over 51\%), the attendees can sign up for the final OKJ exam which consists of a theoretical and practical part in front of a committee. Successful graduates receive a certificate recognised by the state of fencing sport instructor and a certification Europass for the recognition of qualifications in the EU member states and other partners.

The education of fencing coach is also supported by Budapesti Vívó Szövetség - the Budapest Fencing Association (http://budapestivivoszovetseg.hu/) which takes advantage of an opportunity for formal education of its coaches in collaboration with Budapesti Sportszövetségek Uniója - the Union of Sports Associations in Budapest (http://bsu.hu/). Through a system of references from the Union, the Fencing Association can autonomously apply for and issue references for course enrolment in OKJ courses of the Budapest Sports University TE. 
Table 5. The overview of coach education in fencing in Hungary provided by TE

\begin{tabular}{|c|c|c|c|}
\hline & $\begin{array}{l}\text { Fencing bachelor study } \\
\text { programme BA Edző }\end{array}$ & $\begin{array}{l}\text { Coaching course at the } \\
\text { Sports university } \\
\text { Sportedzö tanfolyam } \\
\text { (Sports coach) }\end{array}$ & $\begin{array}{l}\text { Coaching course at the } \\
\text { Sports University } \\
\text { Sportoktató tanfolyam } \\
\text { (Sports instructor) }\end{array}$ \\
\hline $\begin{array}{l}\text { Time alloca- } \\
\text { tion }\end{array}$ & $\begin{array}{l}3 \text { years }-6 \text { semesters }+200- \\
400 \text { lessons of practice. }\end{array}$ & $\begin{array}{l}1,5 \text { year }-3 \text { semesters } \\
\text { (including } 12-15 \text { days of } \\
\text { practice), in total } 400 \text { lessons } \\
\text { of study at } T E+400 \text { lessons } \\
\text { of certified out-of-school } \\
\text { practice }\end{array}$ & $\begin{array}{l}1 \text { year }-2 \text { semesters } \\
\text { (including } 8-10 \text { days), in } \\
\text { total } 200 \text { lessons }\end{array}$ \\
\hline Age limit & $>18$ years of age & $>18$ years of age & $>18$ years of age \\
\hline $\begin{array}{l}\text { Qualification } \\
\text { prerequisites } \\
\text { (fencing expe- } \\
\text { rience) }\end{array}$ & $\begin{array}{l}\text { Passed entrance exams: } \\
\text { written test, oral exam and } \\
\text { practical exam. Acceptance } \\
\text { possible also based on ex- } \\
\text { ceptional sport and coaching } \\
\text { achievements (Olympics, } \\
\text { world championships, } \\
\text { European championships) }\end{array}$ & $\begin{array}{l}\text { A medical certificate, contact } \\
\text { details (e-mail address), } \\
\text { a certificate issued by the } \\
\text { respective sports federation } \\
\text { stating the sports history of } \\
\text { the athlete }\end{array}$ & $\begin{array}{l}\text { A medical certificate, contact } \\
\text { details (e-mail address), } \\
\text { a certificate issued by the } \\
\text { respective sports federation }\end{array}$ \\
\hline Education & $\begin{array}{l}\text { Graduated from a secondary } \\
\text { school (at min.) including } \\
\text { the school-leaving exam }\end{array}$ & $\begin{array}{l}\text { Graduated from a secondary } \\
\text { school (at min.) including } \\
\text { the school-leaving exam }\end{array}$ & Completed basic education \\
\hline
\end{tabular}

\section{DISCUSSION}

The education of fencing coaches receives close attention in all of the observed countries. It is either internal committees functioning as a part of national federations who deal with it or it is dealt with by tertiary educational institutions or the combination of both models. The organisational and content components in these countries differ, with the major difference lying in the system and style of conveying information future coaches are to acquire. Other significant differences were identified in the legislative component. Coach education in the Czech Republic and Hungary is closely linked to the valid legislation specifying training for a pursuit of a profession or it can be perceived as a form of retraining. In the Hungarian system, coaching of fencing can be studied in a bachelor study programme $B Y-\operatorname{Coach}(B A E d z o ́)$. We can find other differences in the length of the programmes (time allocation) of the individual levels of formal education of fencing coaches in the observed countries and in the conception of practical training.

In all three observed countries, the education of fencing coaches is significantly regulated by the respective sports federations or associations. It is especially notable in the case of coach education in Great Britain. The umbrella organisation representing British fencing on international level is the BF. This institution is also in charge of the British Fencing Coaching Framework (British Fencing Coaching Development Framework, 2017, p. 20-21), followed by the EF, WF and NIF. The Scottish Fencing Federation (Scottish Fencing) has its own education system. A characteristic feature of the education of fencing coaches in Britain is legislative autonomy. It is applied only in the obligation to complete the Safeguarding \& Protecting Children Course, the first aid training and the criminal record check. Instruction is provided by BF or SF instructors, external instructors or institutions are engaged only in some cases.

Completing the first aid course is not compulsory in the Czech Republic or Hungary, however, it is included in the syllabi of the lower levels of education. In the case of B and A licence, it is 
a part of the syllabus of the Coaching School and it is taught by FPES experts. The situation is similar in OKJ courses and BA-coach study in Hungary. The Safeguarding \& Protecting Children Course is specific to the Anglo-Saxon context, there is no equivalent in the Czech or Hungarian environment. In the Czech Republic, coach training is realised on lower levels - instructor and $\mathrm{C}$ licence coach are run by the CFF whereby the fencing federation itself determines the content both in terms of teaching theory and practice. Nevertheless, it is not randomly done, the fourlevel system follows principles set by The International Sport Coaching Framework (ICCE, ASOIF \& LBU, 2013).

The education of the A and B licence coaches is provided by the CFF in collaboration with the Fencing School of FPES Charles University, which is in charge of theoretical subjects, namely the Scientific basis of sports training. The specialised practical lessons are provided by the CFF. Within practical teaching in Hungary, students have placements in selected fencing clubs and the specialised lessons are also provided by university experts. In the case of programmes organised for the ICC or FIE Coaching Academy, the situation is similar with the following exception - the FIE arranges practical specialised lessons taught by their own experts.

With regard to legislation, there are several fundamental differences in providing coach education. The Czech system of A and B licence training builds on the association with the Coaching School at FPES, which provides the teaching of theoretical subjects unrelated to the specialisation. The Coaching School provides lessons within the lifelong learning programme and according to the accreditation of the fields of study of the Ministry of Education, Youth and Sport of the CR. The $\mathrm{C}$ licence training and the level instructor is provided solely by the CFF mostly by their internal instructors. In Hungary, the fields of study Sportedzö tanfolyam registered under No. 5481302 (Sports coach with the sport specialised) a Sportoktató tanfolyam registered under No. 3181301 (Sports instructor with the sport specialised) are regulated on a legislative level by rules strictly defining the content of the programmes and are registered in the national register of training - Országos Képzési Jegyzék (OKJ). ${ }^{38}$ Similarly, the bachelor study programme for coaching of fencing is registered at the TE. In Great Britain, however, it is the sports federations (WF, BF, NIF, SF) that are completely in charge of fencing coach education, and this education is independent of government bodies and legislation. The mandatory legislative procedures concern only the completion of first aid courses, Safeguarding \& Protecting Children course and a criminal record check. There is no equivalent to these duties neither in the Czech Republic nor in Hungary.

The systems of coach education in the Czech Republic and Hungary show signs of traditional education of educators in the sports domain. Their advantage is an association with solid educational institutions such as Charles University in Prague or the Testnevelési Egyetem (University of Physical Education) in Budapest. This can, however, significantly affect the approach to the latest trends in education and the needs of coaches as these traditional systems suffer from a certain inertia. The British system is to a certain extent independent. This allows the system to reflect current trends and respond to the ever changing conditions. A disadvantage, on the other hand, is the speed with which the programmes are altered as reported by our informant, a BF member and coach. The current educational system of BF coach education allows the students to choose the direction in which they wish to go and develop, be it the perfection of their technical and tactical level in individual weapons - specialisations or community work in fencing, etc.

Another striking difference is the greater emphasis that the BF and SF place on soft skills in everyday coaching procedures and the application of tools for goal assessment and learning process streamlining. The tools to achieve this are primarily GROW, SMART and SFCP

38 https://www.nive.hu/ 
- Solution Focused Coaching Programme. The partnership with the OpenLearn platform is another innovation in distance teaching. What I consider a disadvantage is the existence of three educational systems (including the British Academy of Fencing - BAF) although membership in the $\mathrm{BF}$ enables the participation in education and recognition of the individual qualification degrees.

The comparison of time allocation (Table 6) in the individual educational systems (leaving out the bachelor study programme at the university in Budapest) shows a distinct disproportion mainly on the higher educational levels of the BF and the Czech and Hungarian systems. The differences are even more striking when comparing the total values, as previously pointed out by Kirby (2014, p. 55). As regards the university degree BA - Coach, the standard training of fencing masters ${ }^{39}$ takes 3 years.

Table 6. Overview of the total time allocation for individual educational systems

\begin{tabular}{|c|c|}
\hline Czech Republic (instructor $\rightarrow$ A licence coach) & $\sum 692$ lessons \\
\hline $\begin{array}{l}\text { Hungary (instructor } \rightarrow \text { coach). University programme } B A \\
E d z o ̈(B A-C o a c h) \text { not included }\end{array}$ & $\begin{array}{l}\sum 1.000 \text { lessons } \\
600+(400 \text { lessons of recognised } \\
\text { practice })\end{array}$ \\
\hline British Fencing: EF, WF and NIF (Core coach $\rightarrow L 4$ ) & $\sum 123$ lessons \\
\hline Scottish Fencing (L1 $\rightarrow$ L5) & $\sum$ cannot be specified \\
\hline
\end{tabular}

As far as the numbers of coaches in the observed countries are concerned, we only have data from Great Britain and their BF Coach Register (https://publish.smartsheet.com/7f681af8be66 4 f46985fa2b238366765), which (as of December 2020) gives a record about 511 active coaches who have met all the requirements for BF membership (in total, however, the register includes 677 people, some of whom are not active or have not fulfilled the BF membership conditions). Most represented in the system are educational levels 2 and 3 (in foil it is 234 out of 423 people; in sabre it is 124 out of 249 and in épée 154 coaches out of 291). A study on fencing coaches conducted by Kirby (2014) revealed the fact that it is namely the most represented educational levels 2 and 3 that the research participants considered to be essential for the development of their coaching competences (Kirby, 2014, p. 55). The given time allocation of formal courses are only the foundation of the education. We need to take into account other forms of coach education (formal and informal) and their everyday practice. The sports history of the given person plays a certain role as well, however, this link (elite athlete $\rightarrow$ expert coach) has not been proven yet (Gilbert, Côté, \& Malle, 2006, p. 74).

The coach register also provides information on other competitive systems of coach education in Great Britain. E.g. for the specialisation of foil out of the total 423 current coaches with a valid licence 18 took advantage of the opportunity to obtain education with the British Academy of Fencing $(4,26 \%)$. Other 25 (5,91\%) obtained a formal education recognised by the BF e.g. by taking a course with the ICC, FIE Coaching Academy or by successful participation in international programmes run by the French or Italian fencing federation (https://publish.smartsheet.co $\mathrm{m} / 7 \mathrm{f} 681$ af 8 be664f46985fa2b238366765). Overall, the percentage of people obtaining alternative education for foil is $10.17 \%$ of registered British coaches. The number of active fencing coaches

\footnotetext{
${ }^{39}$ A custom in the community to address highly acknowledged experts by the expression master, maitre d'armes or maestro di scherma. In certain cases, these expressions are a sign of the highest possible formal education of the given system (e.g. in France and Italy).
} 
in the Czech Republic is not known, however, the database is being developed and will serve among others as a basis for records on mandatory in-service training and participation in the CFF courses. Nevertheless, it is estimated that the number of assistants and coaches is around 250.

The Scottish educational system has its specific characteristics and it is not simple to determine the exact time allocation as it responds to the current needs and also reflects the individual abilities of the participating coaches. In its highest programmes of L4 and L5 though it lasts at least half a year.

The practical teaching in Hungary is run under the supervision of university experts ${ }^{40}$ as well as in the sports clubs where the students do their placements for practice. Right on the premises of the university, there is a fencing hall. An indisputable advantage of the practical training in Hungary is a high level of local fencers and the tradition of a successful sport. It is safe to say that there are many Olympic medalists and world champions of various age categories in Hungarian clubs. This competitive environment and continual high success rate make it possible to draw on experience, absorb it and transform into coaching knowledge and skills that develop in time. Although fencing is not a major sport in Hungary in terms of numbers, it is the most successful one. In the history of the modern Olympics, Hungarian fencers won 37 gold, 23 silver and 27 bronze medals (https://en.wikipedia.org/wiki/Hungary_at_the_Olympics).

In the Czech Republic, experts from the CFF provide the formal education of coaches. Only one expert has ever been engaged to teach all three fencing specialisations. In association with the EMC provision from 2020, the teaching of individual specialisations is delegated on specialists in épée, foil and sabre. Lessons are run in a group of students, there have also been a few intensive camps in the past to hold the practical part. In the informal education of coaches, the CFF often drew on foreign elite coaching experts. However, as pointed out by Kundera (2019a), despite these events, the experience was not passed and shared in the long term in a systematic way, and thus the potential of these events was not fully exploited. The practical training of fencing in Great Britain is provided by local or invited foreign experts.

All the observed levels and educational systems offer study material for their students. Some of them are designed by the instructors themselves and used as PowerPoint presentations in the lectures; some are referred to as the recommended literature for the course, some are provided by the university partner in the process of coach education. In this context, we would like to point out to the TE university e-learning portal (ttps://e-learning.tf.hu/) with study materials for all subjects taught in the bachelor programme BA Edzö (BA-Coach) and the course Sports Coach. Students thus have complete study materials. Furthermore, the website of the Department of Combat sports - Küzdösportok Tanszék (tf.hu/kuzdo) contains teaching aids in the form of 20 accessible publications. ${ }^{41}$ Moreover, since the second half of the $20^{\text {th }}$ till the present, renowned Hungarian coaches have published a number of acclaimed textbooks and texts that have been translated into a number of world languages and are used worldwide as essential literature on fencing (Lukovich, 1986, 1997, 2013; Szepesi, 2009; Szepesi, 2005; Vass, 1976; Beke \& Pologár, 1963; Patócs, 2016; Szabo, 1998).

\footnotetext{
${ }^{40}$ Sabre: Dr. László Szepesi, PhD. (French national team coach, Olympic winner and eight times world champion; won several Hungarian championships and European championship leagues with the VASAS club teams). Ákos Patócs: graduated from the Physical Education University, assistant at TF, former assistant in a coaching course FIE in Budapest (before the FIE Coaching Academy was founded), manager of training camps for Irish and British fencers, the head of the fencing club at the Physical Education University in Budapest, the coach of the national team fencing champions (sabre) to 20 years of age. Foil: István Lukovich, mainly known as the author of professional books on fencing. Kun Csaba - European champion from 1991. Épée: Béla Kopetka: the coach of Imre Géza, the world and European champion and a bronze medalist form the Olympics in Atlanta 1996 (https://fie.org/development/courses/21).

${ }^{41}$ https://tf.hu/intezetek-es-tanszekek/sportagi-intezet/kuzdosportok-tanszek/oktatasi-segedanyagok
} 
In the Czech Republic, the tradition of Methodology newsletters published in the 70s and 80 s of the last century under the patronage of the Czech Union of Sport has been broken. For this reason, Czech coaches, with only rare exceptions (Čivrný, 2018), are forced to study foreign literature or older Czech sources. The topics that resonate most in fencing are history (e.g. Kř́ǐzek, 2014; Angelo, 2018; Čapek, 2012; Habermann, 2014). There are also scholarly studies, e.g. by Štefan Balkó, dealing with the analysis of movement structures and reaction time in fencers (Balkó, 2014; 2016a; 2016b; 2017). The fencing school of FPES provides study materials in the form of comprehensive study texts for theoretical subjects taught in consultations (Jansa \& Dovalil, 2007; Kohlíková, 2004; Perič, 2016).

The British coach education system (BF, SF and BAF) also provides study materials for their students. The portal of accessible materials of the SF has the most elaborate content structure as it also refers to videos documenting examples from coaching practice (https://www.sfcoach. co.uk/level-3; https://www.sfcoach.co.uk/level-2; https://www.sfcoach.co.uk/video). In the case of the BAF, the materials can be purchased for the final exam revision.

\section{CONCLUSION}

The present study of formal educational programmes designed for fencing coaches has confirmed that the observed federations approach coach education differently. The Czech Fencing Federation has stagnated in this respect despite excellent results on the European and world level. In 2020, however, the EMC was founded and introduced new procedural rules regarding coach education. Based on the obtained information, the committee is currently taking measures to optimise the process. The regulations also include a provision related to mentoring and continuous education by means of compulsory in-service seminars and training.

Thus, a systematic approach towards fencing coach education in the Czech Republic has been laid again. Another turning point in the history of coach education at the CFF is delegating instructors for specific weapons while in the past, the practical lessons in formal courses for all three specialisations were taught by a single instructor.

In Hungary, the legacy of generations of successful fencers, the opportunity to collaborate with renowned domestic coaches of fencing affiliated with the structure of university education allows great professional development of Hungarian coaches of fencing. Also, thanks to these circumstances, Hungarian fencers are the third most successful nation in the world in fencing. Compared to other fencing superpowers with multiple times many more members, the quality and stability of their results are remarkable.

The British system associated with the British Fencing Coaching Framework as well as coach education in Scotland approaches the issue of coach education with a slightly different philosophy compared to the traditional systems of the Czech Republic and Hungary. The application of modern educational methods (SFCP), e-learning courses and the collaboration with widely acclaimed experts brought about a wide-scale increase in the performance level of British fencing. The strong economy and the possibilities to employ foreign coaches also contribute to the success.

The work that has begun on the revival of systematic coach education in the Czech Republic has been strongly encouraged and supported by the CFF. Another significant factor is active participation in the process of the development of fencing coaches represented by Fridrich Földes, a widely acclaimed coach with rich experience in pentathlon and expert knowledge who can become a patron of this process. 
Dedication: This study was conducted at Masaryk University as a part of a project "Comparison of formal education systems for fencing coaches in Hungary, Great Britain and the Czech Republic" No MUNI/A/1232/2019 supported from the targeted funds for specific research provided by the Ministry of Education, Youth and Sports in 2020.

\section{References}

Academie d'Armes Internationale. (n.d.). Retrieved November 5, 2020, from http://www.aai.world/

Accredited Coaches. (n.d.). Retrieved November 18, 2020, from British Fencing: https://www.britishfencing.com/accreditedcoaches/

Avard, F. (1995). Systematic observation of a winning football coach. Louisiana Association for Health, Physical Education, Recreation, and Dance, 59(1), 11-12.

BA Edző. (n.d.). Retrieved November 1, 2020, from Testnevelési Egyetem: https://tf.hu/felvetelizok-kepzeseink/ba-bscszakok/ba-edzo

Balko, Š. (2016a). The surface electromyography in fencing: The analysis of the acyclic movement in three different performance level groups of fencers. Opole: Opole University of Technology.

Balkó, Š., Balkó, I., \& Süss, V. (2014). Analýza pohybové struktury výpadu u dvou výkonnostně odlišných skupin šermírů. Studia sportiva, 8(2), 85-92. doi:10.5817/StS2014-1-9

Balkó, Š., Borysiuk, Z., \& ŠimoneK, J. (2016b). The influence of different performance level of fencers on simple and choice reaction time. Revista Brasileira de Cineantropometria \& Desempenho Humano, 18(4), 391-400. doi:https://doi. org/10.5007/1980-0037.2016

Balkó, Š., Rous, M., Balkó, I., \& Borysiuk, Z. (2017). Influence of a 9-week training intervention on the reaction time of fencers aged 15 to 18 years. Physical Activity Review, 5, 146-154. doi:10.16926/par.2017.05.19

Bartoš, J. (1992). Úvod do metodiky a techniky historické práce. Olomouc: Univerzita Palackého.

Beke, Z., \& Polgár, J. (1963). The methodology of sabre fencing. Budapest: Corvina Press.

Bereday, G. Z. (1964). Comparative method in education. New York, NY: Holt, Rinehart and Winston.

Berelson, B. (1952). Content analysis in communication research. Glencoe, Ill.: Free Press.

BF Coach Register December. 2020. (n.d.). Retrieved December 29, 2020, from British Fencing: https://publish.smartsheet. com/7f681af8be664f46985fa2b238366765

Bidlo, B. (1975). Volná šermírská utkání jako součást tréninkového procesu. Praha: Ústřední výbor Československého svazu tělesné výchovy.

Borysiuk, Z. (2009). Modern Saber Fencing. Technique - Tactics - Training - Research. New York: SKA SwordPlay Books.

British Academy of Fencing. (n.d.). Retrieved November 28, 2020, from https://baf-fencing.com/the-baf-and-british-fencing/

British Fencing Coaching Development Framework. (2017, April). The Sword, 20-21. Retrieved from http://britishfencing. com/uploads/files/the-sword-april-2017.pdf

British Fencing Coaching Framework. (n.d.). Retrieved November 5, 2020, from British Fencing: https://www.britishfencing. com/members/coaching-zone/the-bf-coaching-framework/

Coach Zone. (n.d.). Retrieved November 18, 2020, from British Fencing: https://www.britishfencing.com/members/coachingzone

Coach's Journey. (n.d.). Retrieved from British Fencing: https://www.britishfencing.com/members/ coaching-zone/the-bfcoaching-framework/my-coachs-journey/

Coaching Fencing Course (L2). (n.d.). Retrieved November 15, 2020, from British Fencing: https://www.britishfencing.com/ members/coaching-zone/the-bf-coaching-framework/my-coachs-journey/coaching-fencing-course-I2/

Coaching System. (n.d.). Retrieved November 5, 2020, from Welsh Fencing: https://www.welshfencing.org/index.php/ component/content/article/10-coaching/650-coaching-system?Itemid=101

Cook, T. A. (Ed.). (1909). The Fourth Olympiad 1908: Being the Official Report of The Olympic Games of 1908, celebrated in London, under the patronage of His Most Gracious Majesty King Edward VII and by the sanction of The International Olympic Committee. London: The British Olympic Association. Retrieved from https://digital.la84.org/digital/collection/p17103coll8/id/8958/

Core Coach Overview. (n.d.). Retrieved November 15, 2020, from British Fencing: https://www.britishfencing.com/members/coaching-zone/the-bf-coaching-framework/my-coachs-journey/core-coach-offer/core-coach-course-overview/

Côté, J., Salmela, J., Trudel, P., Baria, A., \& Russel, S. (1995). The coaching model: A grounded assessment of expert gymnastic coaches' knowledge. Journal of Sport \& Exercise Psychology, 17(1), 1-17. Retrieved from https://journals.humankinetics. com/view/journals/jsep/17/1/article-p1.xml

Čapek, M. (2012). Historie českého šermu od jeho počátků do roku 1938. (Thesis). Praha: Karlova univerzita. Retrieved from https://dspace.cuni.cz/handle/20.500.11956/44436

Český šermířský svaz. (2020, January 19). Směrnice a kritéria trenérských licencí. Retrieved 11 19, 2020, from https://www. czechfencing.cz/uploads/documents/119.pdf

Čivrný, Č. (2018). Šerm Fleretem: Historie a metodika. Praha: Elka Press.

De Beaumont, C. (1966). Modern British Fencing 1957-1964. London: Nicholas Kaye. 
Dieffenbach, K., \& Thompson, M. (Eds.). (2020). Coach Education Essentials. Champaign, II.: Human Kinetics.

Dovalil, J. (2014). Trenérská škola fakulty tělesné výchovy a sportu [anglický název]. In L. Flemr, J. Němec, \& O. Novotný (Eds.), Pohybové aktivity ve vědě a praxi: konferenční sborník u príležitosti 60. výročí založení Fakulty tělesné výchovy a sportu Univerzity Karlovy v Praze (pp. 339-352). Praha: Karolinum.

Dreyfus, S., \& Dreyfus, H. (1980). A five-stage model of the mental activities involved in directed skill acquisition. Retrieved from https://www.researchgate.net/publication/235125013_A_Five-Stage_Model_of_the_Mental_Activities_Involved_in_ Directed_Skill_Acquisition

Eating to win: activity, diet and weight control. (n.d.). Retrieved November 26, 2020, from OpenLearn: https://www.open. edu/openlearn/health-sports-psychology/sport-fitness/eating-win-activity-diet-and-weight-control/content-section0 ?active-tab=description-tab

England Fencing. (n.d.). Retrieved from http://englandfencing.co.uk/

Evidence programů CŽV: Trenérská škola - licence A (2020-2021). (n.d.). Retrieved November 6, 2020, from Informační systém UK: https://is.cuni.cz/studium/ekczv/index.php?do=detail\&cid=6482

Exploring sport coaching and psychology. (n.d.). Retrieved November 26, 2020, from OpenLearn: https://www.open.edu/ openlearn/health-sports-psychology/exploring-sport-coaching-and-psychology/content-section-overview?activetab=description-tab

Gálová, T., \& Jůva, V. (2019). Development of non-formal sports coach education. Studia sportiva, 12(2), 122-135. doi:https:// doi.org/10.5817/StS2018-2-12

Gálová, T., \& Jůva, V. (2019). Organizační a obsahové trendy trenérského vzdělávání [Organizational and Content Trends of Coach Education]. Studia sportiva, 12(2), 122-135.

Gavora, P. (2000). Úvod do pedagogického výzkumu. Brno: Paido.

Gilbert, W., Côté, J., \& Mallett, C. (2006). Developmental Paths and Activities of Successful Sport Coaches. International Journal of Sports Science \& Coaching, 1(1), 69-76. https://doi.org/10.1260/174795406776338526

Gobinder, G. (2014). The Nature of Reflective Practice and Emotional Intelligence in Tutorial Settings. Journal of Education and Learning, 3(1), 86-100. doi:10.5539/jel.v3n1p86

Gray, E., \& Cohen, R. (1984). Modern British Fencing: History of the Amateur Fencing Association 1964-1981. London: Amateur Fencing Association.

Grexa, J., \& Strachová, M. (2011). Dějiny sportu: Přehled světových a českých dějin tělesné výchovy a sportu. Brno: Masarykova univerzita.

Habermann, D. (2014). Př́nos Hergsellů pro šermírské umění 2. pol. 19. Století. (Thesis). Brno: Masarykova univerzita. Retrieved from https://is.muni.cz/th/onpuv/Prinos_rodu_Hergselu_pro_serm._umeni_v_2._pol._19._stol.pdf

Hedlund, D., Fletcher, C., Pack, S., \& Dahlin, S. (2018). The Education of Sport Coaches: What Should They Learn and When Should They Learn It? International Sport Coaching Journal, 5(2), 192-199. doi:https://doi.org/10.1123/iscj.2017-0110

Hendl, J. (2005). Kvalitativní výzkum: základní metody a aplikace. Praha: Portál.

Hergsell, G. (1896). Die Fechtkunst im XV. und XVI. Jahrhunderte. Praha: Selbstverlag.

Hroch, M. (1985). Úvod do studia dějepisu. Praha: Státní pedagogické nakladatelství.

Hungary at the Olympic. (n.d.). Retrieved November 30, 2020, from Wikipedia: https://en.wikipedia.org/wiki/Hungary_at_ the_Olympics

Hutton, A. (1889). Cold Steel: A practical Treatise on the sabre. London: William Clowes and sons.

Child Wellbeing and Protection in Sport. (n.d.). Retrieved November 26, 2020, from https://sportscotland.info/childwellbeing/v4/index.html

ICCE, ASOIF, \& LBU. (2013). The International Sport Coaching Framework, v1.2. Champaign, Il.: Human Kinetics.

Introduction to Coaching Fencing (L1). (n.d.). Retrieved November 15, 2020, from British Fencing: https://www.britishfencing. $\mathrm{com} / \mathrm{members} / c o a c h i n g-z o n e /$ the-bf-coaching-framework/my-coachs-journey/introduction-to-coaching-fencing/

Janíková, M., Jůva, V., \& Cacek, J. (2019). Sportovní trenér: vymezování profese a její různé podoby a problémy [Sports Coach: Evolving the Profession and Its Various Forms and Challenges]. Orbis Scholae, 13(1), 63-64.

Jansa, P., \& Dovalil, J. (2007). Sportovní príprava. Příbram: bptisk.

Jones, L. (2017, April). The Structure of Coaching in the UK. The Sword, 22-23. Retrieved from http://britishfencing.com/ uploads/files/the-sword-april-2017.pdf

Jůva, V. (2011). Neformální vzdělávání sportovních trenérů [anglický název]. In T. Janík, P. Knecht, \& Š. Šebestová (Ed.), Smíšený design v pedagogickém výzkumu: Sborník príspěvků z 19. výroční konference České asociace pedagogického výzkumu (pp. 274-279). Brno: Masarykova univerzita. doi:10.5817/PdF.P210-CAPV-2012-19

Kirby, D. J. (2014). From Piste to Podium: a qualitative exploration of the development of fencing coaching in Britain. (Thesis). Birmingham: University of Birmingham. Retrieved from https://etheses.bham.ac.uk/id/eprin

Klučina, P., Romaňák, A., Finková, D., \& Pokorná, A. (1995). Rytiríi: Historie vojenství od starověku až po 19. století. Praha: Fragment.

Kogler, A. (2005). One touch at time: Psychological Processes in Fencing. New York: SKA SwordPlay Books.

Kohlíková, E. (2004). Fyziologie člověka: Učební texty pro trenérskou školu FTVS UK v Praze. Praha: Univerzita Karlova.

Kovář, K. (2011). Současné trendy ve vzdělávání trenérů. Česká kinantropologie, 15(3), pp. 11-16.

Křížek, L. (2014). Historie evropských duelů a šermu (Vol. III. Od duelového ke sportovnímu kolbišti). Praha: Mladá fronta.

Kundera, V. (2019a). Model vzdělávání trenérů šermu v České republice [Model of education of fencing coaches in Czech Republic]. (Dissertation). Brno: Masarykova univerzita. Retrieved from https://is.muni.cz/th/pstsm/ 
STUDIA SPORTIVA 2021/2

Kundera, V. (2019b). Analýza vzdělávání trenérů šermu v České republice [Analysis of education of fencing coaches in the Czech Republic]. Studia sportiva, 12(2), 157-165. doi:https://doi.org/10.5817/StS2018-2-15

Lara-Bercial, S., Jimenez, A., Abraham, A., Bales, J., Colmaire, P., Curado, J., . . Rynne, S. (2016). International Sport Coaching Bachelor Degree Standards of the International Council for Coaching Excellence. International Sport Coaching Journal, 3(3), 344-348. doi: https://doi.org/10.1123/iscj.2016-0085

Le Goff, J., \& Schmitt, J. (2020). Encyklopedie středověku. Praha: Vyšehrad.

Licence A. (n.d.). Retrieved November 6, 2020, from Fakulta Tělesné výchovy a sportu Univerzita Karlova: https://ftvs.cuni. cz/FTVS-2198.html

Licence B. (n.d.). Retrieved November 6, 2020, from Fakulta Tělesné výchovy a sportu Univerzita Karlova: https://ftvs.cuni. cz/FTVS-2199.html

Lukovich, I. (1986). Fencing. Budapest: Corvina.

Lukovich, I. (1997). Fencing: The Modern International Style. New York: SKA Swordplay Books.

Lukovich, I. (2013). Foil Fencing: Technique, Tactics, and Training. A manual for Coaches and Coaching Candidates. New York: SwordPlay Books.

Lyle, J. (2016). Sports Coaching Concepts: A Framework for Coaches'Behaviour. London: Routledge: Routledge.

Macnamara, J. (2018). Content Analysis. In P. M. Napoli (Ed.), Mediated Communication (pp. 191-212). Berlin, Boston: Walter de Gruyter GmbH \& Co KG. doi:10.1515/9783110481129-012

Mallett, C., Trudel, P., Lyle, J., \& Rynne, S. (2009). Formal vs. Informal Coach Education. International Journal of Sports Science \& Coaching, 4(3), 325-334.

Maňák, J., \& Švec, Š. (2005). Slovník pedagogické metodologie. Brno: Masarykova univerzita and Paido.

Marácz, L. (2019). Saber Fencing and the Remaking of the Hungarian State. Erdélyi Társadalom/Transylvanian Society, 17(1), 21-37. doi:https://doi.org/10.17177/77171.222

Marinková, H., \& Stretti, M. (2009). Formální vzdělávání, neformální vzdělávání, informální učení. In J. Průcha (Ed.), Pedagogická encyklopedie (pp. 247-251). Praha: Portál.

Mayer, J. (2018). Šerm mečem. (2. ed.). Olomouc: Guildam Gladiatorum.

Motivation and factors affecting motivation. (n.d.). Retrieved from OpenLearn: https://www.open.edu/openlearn/healthsports-psychology/motivation-and-factors-affecting-motivation/content-section-0?active-tab=description-tab

Nemzeti Szakképzési és Felnőttképzési Hivatal. (n.d.). Retrieved from https://www.nive.hu/Northern Ireland Fencing. (n.d.). Retrieved from https://www.nifencing.com/

Olivová, V. (1979). Lidé a hry. Praha: Olympia.

Organizační, studijní a zkušební rád TŠ. (2009, July 7). Retrieved November 16, 2020, from https://ftvs.cuni.cz/FTVS-2198version1-organizacni_studijni_a_zkusebni_rad_ts.pdf

Patócs, A. (2016). Interact fencing: Sabre. Publio Kiadó.

Perič, T. (. (2016). Školení trenérů lic. B: Podklady pro přednášky. Praha: UK FTVS.

Randall, N. (2009, January). Coach Development Project. The Sword, 4-17.

Reade, I. (2009). Formal vs. Informal Coach Education: A Commentary. International Journal of Sports Science \& Coaching, 4(3), 343-346. Retrieved from https://eds.b.ebscohost.com/eds/pdfviewer/pdfviewer?vid=2\&sid=953b7a7a-c30e4cad-b4e4-c6e75da09bb9\%40pdc-v-sessmgr04

Recovery strategies in sport and exercise. (n.d.). Retrieved from OpenLearn: https://www.open.edu/openlearn/health-sportspsychology/recovery-strategies-sport-and-exercise/content-section-0?active-tab=description-tab

Roček, M. (2020a). Educational Activities of the International Fencing Federation (FIE) "FIE Budapest Coaching Academy". Studia sportiva, 13(2), 94-96. doi:10.5817/sts2019-2-9

Roček, M. (2020b). Vyhodnocení dotazníku VzMK č. 1. Retrieved from Český šermírský svaz: https://www.czechfencing.cz/ uploads/documents/126.pdf

Safeguarding: Fencing-Specific Online Renewal Course Now. (n.d.). Retrieved from British Fencing: https://www.britishfencing.com/safeguarding-fencing-specific-online-renewal-course-now-available/

Scottish Fencing. (n.d.). Retrieved November 15, 2020, from http://www.scottish-fencing.co.uk/

Scottish Fencing Coach Programme. (n.d.). Retrieved November 26, 2020, from https://www.sfcoach.co.uk/

Scottish Fencing Coach Programme - L. 1 Volunteer. (n.d.). Retrieved November 26, 2020, from https://cd8cee8381ef-442d-b657-0b93af851eba.filesusr.com/ugd/830e40_06e16bb0b8db4fe4a632a04af9e3f800.pdf

Scottish Fencing Coach Programme - L. 2 Community. (n.d.). Retrieved November 26, 2020, from https://cd8cee8381ef-442d-b657-0b93af851eba.filesusr.com/ugd/830e40_3013212cc85346a7b5a6c7ef4f885eb1.pdf

Scottish Fencing Coach Programme - L. 3 Club Coach. (n.d.). Retrieved November 26, 2020, from https://cd8cee8381ef-442d-b657-0b93af851eba.filesusr.com/ugd/830e40_a54cbef4f94a4209920ef184f34f9232.pdf

Scottish Fencing Coach Programme - L. 4 Talent. (n.d.). Retrieved November 26, 2020, from https://cd8cee83-81 ef-442d-b6570b93af851eba.filesusr.com/ugd/830e40_b56433d4764b4d6b94986be46a13d935.pdf

Scottish Fencing Coach Programme - L. 5 Performance. (n.d.). Retrieved November 26, 2020, from https://cd8cee8381 ef-442d-b657-0b93af851eba.filesusr.com/ugd/830e40_00dc59d1c5ff4cec89d00ece5b0b5a4e.pdf

Scottish Fencing. (n.d.). Scottish Fencing Code of Conduct for Safeguarding Children in Sport. Retrieved November 26, 2020, from http://www.scottish-fencing.co.uk/sites/default/files/SF\%20CodeofConduct_0.doc

Sedlák, A. (1982). Šerm pro trenéry III. a II. třídy. Praha: Tělovýchovná škola ČúV ČSTV.

Směrnice a kritéria trenérských licencí. (n.d.). Retrieved November 6, 2020, from Český šermiŕský svaz: https://www.czechfencing.cz/uploads/documents/119.pdf 
Sportedző tanfolyam. (n.d.). Retrieved November 1, 2020, from Testnevelési Egyetem: https://tf.hu/kepzeseink/okj/sportedzo-tanfolyam

Sportoktató tanfolyam. (n.d.). Retrieved from Testnevelési Egyetem: https://tf.hu/kepzeseink/okj/sportoktato-tanfolyam Szabó, L. (1998). Fencing and the Master. New York: SKA Swordplay Books.

Szakdolgozat Témák. (n.d.). Retrieved from Testnevelési Egyetem: https://tf.hu/intezetek-es-tanszekek/sportagi-intezet/ kuzdosportok-tanszek/szakdolgozat-temak

Szepesi, L. (2007). Fencing: how to design success - Competition training and competitive preparation at top level. Studia Educatio Artis Gymnasticae (1), 75-88. Retrieved from http://studia.ubbcluj.ro/download/pdf/283.pdf

Szepesi, L. (2009). Learning Fencing in Groups: Methodological Collection of Exercises. Passau: Schenk Verlag.

Švec, Š. (2009). Metodologie věd o výchově. Brno: Paido.

Taušová, O. (2012). Formy vzdělávání trenérů alpských disciplín - komparace České republiky a Spojených států amerických [Educational Forms of Alpine Ski Coaches - Comparation of the Czech Republic and the United States of America]. (Dissertation). Brno: Masarykova univerzita. Retrieved from Brno. https://is.muni.cz/th/z1 ew2/

TE E-Learning. (n.d.). Retrieved from Testnevelési Egyetem: https://e-learning.tf.hu/Testnevelési Egyetem (University of Physical Education). (n.d.). Retrieved November 1, 2020, from https://english.tf.hu/

Thompson, C. (2010). Highland Broadsword: Lesson, Drills, and Practices. Boulder: Paladin Press. Boulder: Paladin Press.

Tobolka, M. (2016). Paulus Hector Mair (cca 1517-1579). Studia Historica Nitriensia, 20(2), 525-530. Retrieved from http:// www.shnnitra.ff.ukf.sk/wp-content/uploads/Tobolka-2016-2.pdf

Tomešová, B. (2020). Vzdělávání trenérů SpS v biatlonu [Biathlon coaches education]. (Thesis). Brno: Masarykova univerzita. Retrieved from https://is.muni.cz/th/oyglk/

Trudel, P., \& Gilbert, W. (2006). Coaching and coach education. In D. Kirk, M. O'Sullivan, \& D. McDonald (Eds.), Handbook of physical education (pp. 531-554). Thousand Oaks: Sage.

Trudel, P., \& Gilbert, W. (2006). Coaching and Coach Education. In D. Kirk, D. Macdonald, \& M. O'Sullivan (Eds.), Handbook of Physical Education (pp. 516-539). London: SAGE Publications.

U.S. Center for SafeSport. (n.d.). Retrieved November 15, 2020, from https://safesport.org/

United States Olympic Committee. (2017). Quality Coaching Framework. Champaign, II: Human Kinetics. Retrieved from https://assets.ngin.com/attachments/document/0138/3102/USOC_QCF_FINAL.pdf

Vass, I. (1976). Épée Fencing. Budapest: Corvina.

Vívóedző-képzés a TE-n [Fencing coach studium at TE]. (n.d.). Retrieved January 10, 2021, from Magyar Vívó Szövetség: https://hunfencing.hu/hir/vivoedz-kepzes-a-te-n-4206

Vodička, O., \& Fabian, M. (2018). Šerm majstra Lichtenauera: Antologia šermiarskych naukzo stredovekej Europy. Bratislava: CBS.

Weapon Specific Course (L3). (n.d.). Retrieved November 15, 2020, from British Fencing: https://www.britishfencing.com/ members/coaching-zone/the-bf-coaching-framework/my-coachs-journey/weapon-specific-course-I3/

Weapon Specific Course (L4). (n.d.). Retrieved November 15, 2020, from British Fencing: https://www.britishfencing.com/ members/coaching-zone/the-bf-coaching-framework/my-coachs-journey/weapon-specific-course-14/

Welsh Fencing. (n.d.). Retrieved from https://www.welshfencing.org/

Werner, P., Thorpe, R., \& Bunker, D. (1996). Teaching Games for Understanding: Evolution of a Model. Journal of Physical Education, Recreation \& Dance, 67(1), 28-33. doi:10.1080/07303084.1996.10607176

Whitmore, J. (2009). Coaching for performance: GROWing human potential and purpose: the principles and practice of coaching and leadership. (4 ed.). Boston: Nicholas Brealey.

\section{Contact Information:}

Michal Roček, Faculty of Sports Studies, Masaryk University, michal.rocek@fsps.muni.cz 